\title{
Aspects of peridomiciliary ecotopes in rural areas of Northeastern Brazil associated to triatomine (Hemiptera, Reduviidae) infestation, vectors of Chagas disease
}

\author{
Otília Sarquis, Ricardo Sposina, Tiago Guedes de O liveira, José Roberto Mac Cord, \\ Pedro Hernan Cabello*, José Borges-Pereira**, Marli Maria Lima/ ${ }^{+}$
}

Departamento de Biologia *Departamento de Genética **Departamento de Medicina Tropical, Instituto Oswaldo Cruz-Fiocruz, Av. Brasil 4365, 21045-900 Rio de Janeiro, RJ, Brasil

Artificial ecotopes of 121 peridomiciliary environments in four rural localities in the state of Ceará, Brazil, were studied and the type of material of the ecotopes was identified as triatomine infestation. Two thousand two hundred and four Triatoma brasiliensis Neiva, 340 Triatoma pseudomaculata Corrêa and Espinola, 121 Rhodnius nasutus Stall, and 5 Panstrongylus lutzi (Neiva and Pinto) were captured. Out of the 323 ecotopes found $(\overline{\mathrm{X}}=2.0 \pm 1.8$ per dwelling) - such as pigpens, henhouses, corrals, perches, dovecotes, piles of roofing tiles, bricks, wood, and straw $-30.3 \%$ were infested by triatomines in all different developmental stages, including eggs. A substantial number of triatomines were found in perches, however the largest infestation took place in roofing materials used in the construction of goat/sheep corrals, henhouses, and pigpens, where 98\% of them were captured: 1372 triatomines were located in the roofing tile covers, 285 in the straw, 187 in the perches, 77 in the coverings of roofing tiles and straw, and 13 in the straw and wood. Among all the different pile of materials, roofing tiles were the most infested $(50 \%)$ followed by bricks (38.9\%) and woods (36.1\%). T. brasiliensis colonized mainly brick piles $\left(\chi^{2}=16.539 ; p<\right.$ $0.05)$ and roofing tiles $\left(\chi^{2}=5,090.58 ; p<0.05\right)$; T. pseudomaculata preferred wood perches $\left(\chi^{2}=472.39 ; p<0.05\right)$ and woodpiles $\left(\chi^{2}=126.0 p<0.05\right)$, and $\mathrm{R}$. nasutus was principally found in roofing straw $\left(\chi^{2}=384.43 ; p<0.05\right)$. These findings suggest that triatomines tend to colonize peridomiciliary ecotopes similar to their original habitats.

Key words: triatomines - ecotopes - peridomicile - Chagas disease - Northeastern Brazil

Triatoma infestans (Klug) has been chemically controlled in an effective manner by a joint program involving the Southern Cone countries (Silveira 2002). However, a new endemic epidemiological picture of Chagas disease may arise caused by the growing rate of the wild or peridomiciliated species domiciliation (Silveira et al. 2001). Within this context, T. brasiliensis and T. pseudomaculata have become particularly important, mainly because they have been frequently and persistently found infesting dwellings, principally in the Brazilian Northeast region, in addition to the high natural infection rate by Trypanosoma cruzi Chagas (Costa et al. 2003). Rhodnius nasutus Stall is another triatomine present in that region that can take part in the transmission of $T$. cruzi in the domestic cycle. This species is predominantly wild, nevertheless, it has been frequently found colonizing artificial peridomiciliary ecotopes, often presenting high indices of $T$. cruzi infection (Silveira \& Vinhaes 1998, Sarquis et al. 2004).

The municipality of Jaguaruana, located in the state of Ceará, has been considered by the Chagas Disease Control Program (PCDCh/FNS) as one of the highest endemic regions for American tripanosomiasis (Bezerra et al. 2004). The Brazilian National Health Foundation and the State Health Department of Ceará have been trying to

Financial support: Papes III/Fiocruz, CNPq, Faperj

+Corresponding author: mmlima@ioc.fiocruz.br

Received 2 September 2005

Accepted 15 February 2006 maintain a periodical control system spraying all domiciliary units where the presence of bugs is confirmed; however, these vectors are still frequently found mainly in the peridomicilium of rural areas (Sarquis 2003, Lima et al. 2004, Sarquis et al. 2004).

The aim of this paper is to analyze the characteristics of peridomiciliary artificial ecotopes found in rural areas of Jaguaruana, associating them with infestation and colonization by triatomines and also to determine which of those ecotopes are the best suited for installation and development of the Chagas disease vectors.

\section{MATERIALS AND METHODS}

Jaguaruana municipality is located in a hot and dry region in the eastern of the state of Ceará, about $180 \mathrm{~km}$ from Fortaleza; the average annual temperature ranges from $23^{\circ} \mathrm{C}$ to $33^{\circ} \mathrm{C}$, and rainfall is approximately $850 \mathrm{~mm}$ per year; the vegetation coverage is compound of spinous caducifolius forest and dense arbustive caatinga, presenting some areas in accentuated degradation. The municipality contains 156 localities in the rural area. Peridomiciles of four of these localities - Currais do Felipe, Coberto, Figueiredo, and Figueiredo do Bruno - were investigated. Coberto has $3 \mathrm{~km}^{2}, 15$ domiciles, and 61 inhabitants; Currais do Felipe has $3,5 \mathrm{~km}^{2}, 19$ domiciles, and 76 inhabitants; Figueiredo do Bruno has $4 \mathrm{~km}^{2}$, 41 domiciles, and 146 inhabitants; Figueiredo has $8 \mathrm{~km}^{2}, 83$ domiciles, and 348 inhabitants; the four localities totalize 158 dwellings, and approximately 630 people living there.

Peridomicilium was considered to be the area situated within $100 \mathrm{~m}$ proximity the dwellings. Henhouses, pig- 


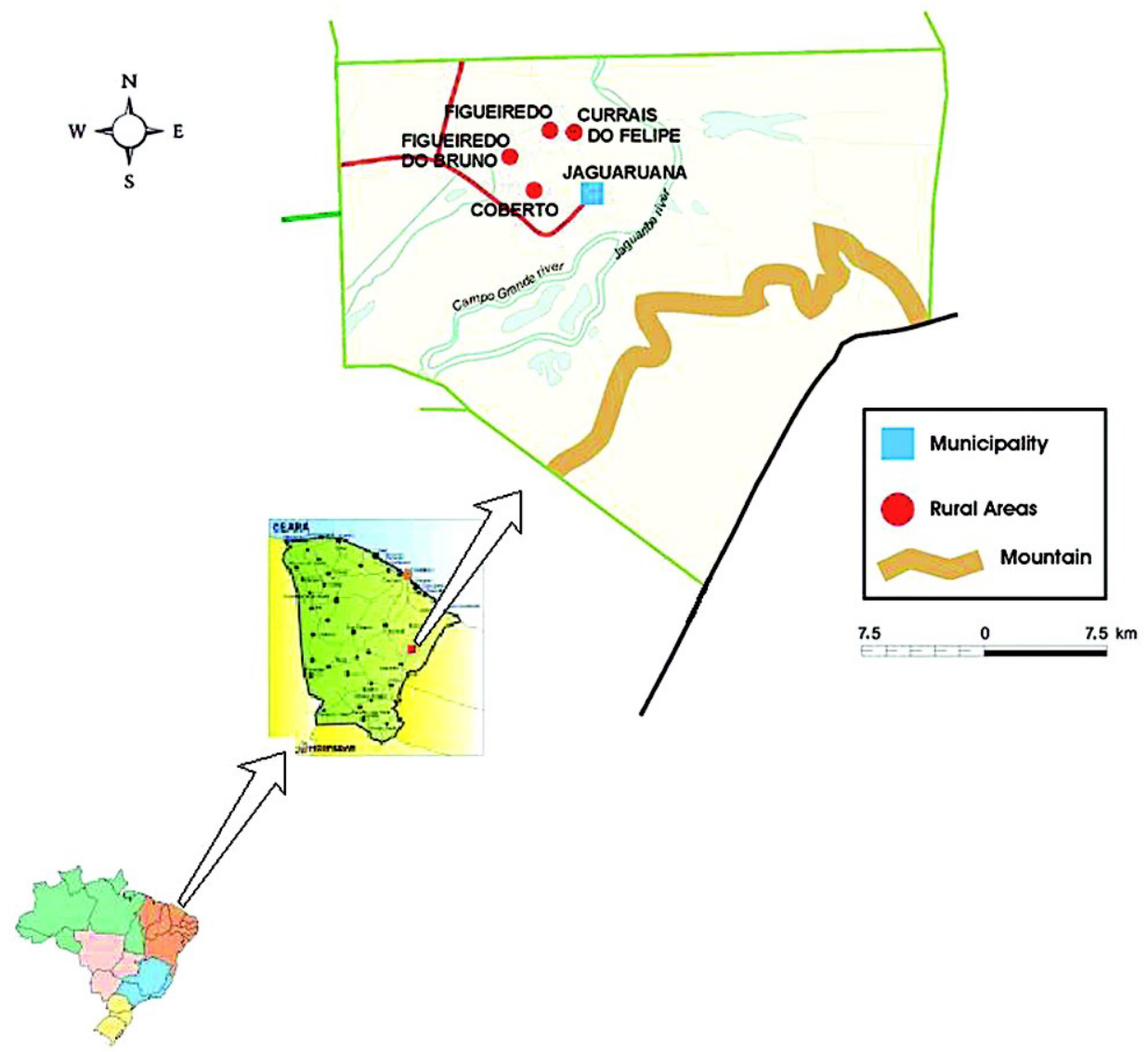

Map of the municipality of Jaguaruana, state of Ceará, Brasil, showing the geographic location of the surveyed ares.

pens, corrals, perches, piles of tiles, bricks, wood, and straw were analyzed regarding quantity, distance to the dwelling, presence or absence of roofing, type of construction, material, and infestation by triatomines. Domestic animals present in each peridomicilium were quantified by ecotope.

In each of the peridomiciles, two men per ecotope, with the aid of tweezers, exhaustively performed five manual triatomine captures within the period between November 2000 and April 2002; no dislodging substances were used. All annexes were carefully checked. The captured triatomines were stored in labeled plastic containers and forwarded to the laboratory for identification, according to the criteria proposed by Lent and Wygodzinsky (1979).

The Chi-square test was carried out to estimate the preference of the different triatomine species for each ecotope. The Spearman test correlated the density of the triatomine population of each ecotope with the number of animals present.

\section{RESULTS}

Among the 158 domiciliary units studied, 121 peridomiciles displayed ecotopes, on a mean of $2.0 \pm 1.8$ (median and mode $=2$ ) per domiciliary unit, including animal shelters and piles, all of them having been there for a long time. Domestic animals were found in $91.1 \%$ of the dwell- ings; most were fowl, followed by goat/sheep, cows, pigs, dogs, cats, and horses; residents reported that they frequently encounter mice inside and opossums and crabeating foxes (Cerdocyom thous) in proximity to the houses.

Triatomines in different developmental stages and eggs were found in $30 \%$ of the ecotopes, $68.7 \%$ being shelters for domestic animals, and $32.3 \%$ piles of bricks, roofing tiles or wood. Most shelters contained walls composed of carnauba wax palm (Copernicia prunifera) or black quince trees (Croton sonderianus) trunks and were roofed with tile, straw or wood. Out of the infested ecotopes, $7.4 \%$ were directly linked to the house walls and $66.3 \%$ were located within $10 \mathrm{~m}$ vicinity of the houses.

The largest infestation rate occurred in goat/sheep corrals $(40.4 \%)$, followed by perches $(34.4 \%)$, henhouses $(26.2 \%)$, and pigpens $(21.1 \%)$. In piles of roofing tiles, bricks, and wood the average percentages of infestation were $50.5,38.9$ and $36.1 \%$, respectively. Cattle corrals, dovecotes and piles of straw were not infested. Triatomines ehxibited clear preference for roofs, where $98 \%$ were captured. A total of 2670 triatomine specimens were captured: 2204 T. brasiliensis, 340 T. pseudomaculata, 121 $R$. nasutus, and 5 Panstrongylus lutzi.

T. brasiliensis displayed a significantly higher preference for wood animal shelters with roofing tiles $\left(\chi^{2}=\right.$ 5,090.58; $\mathrm{p}<0.05)$. T. pseudomaculata and $R$. nasutus preferred perches $\left(\chi^{2}=472.39 ; \mathrm{p}<0.05\right)$ and wood shel- 
ters with straw roofs $\left(\chi^{2}=384,43 ; \mathrm{p}<0.05\right)$, respectively (Table I).

T. brasiliensis and T. pseudomaculata were found in all infested piles, nevertheless, the former showed significant preference for brick piles $\left(\chi^{2}=16.39 ; \mathrm{p}<0.05\right)$ and the latter for wood piles $\left(\chi^{2}=126.0 ; \mathrm{p}<0.05\right)$. R. nasutus was exclusively found in wood piles and $P$. lutzi was captured only in piles of roofing tile (Table I).

Colonies of T. brasiliensis of all sizes were recorded, some of them with more than 100 specimens. This species was found colonizing all types of infested ecotopes, mainly wood shelters with tile roofing and brick piles. T. pseudomaculata was also capable of colonizing certain peridomiciliary ecotopes and of forming colonies of up to 50 specimens, with preference for perches and woodpiles. Although $R$. nasutus was found in smaller amounts, it colonized mainly wood shelters with straw roofing, where it formed at least one 50-specimen colony. This species was also capable of colonizing perches and woodpiles, with one colony each (Tables II, III).
$R$. nasutus was not found isolated in any of the six colonies; in four of them it cohabitated with $T$. pseudomaculata and in two others with $T$. brasiliensis and T. pseudomaculata. These last two species formed isolated colonies; when they cohabitated with T. brasiliensis, this species prevailed.

The correlation analysis between the density of triatomines and the number of domestic animals present in each ecotope did not present a significant value (Table IV). Nevertheless, the correlation between the number of pigs and captured triatomine $(r=0.6849)$ presented a borderline value with $5 \%$ significance.

\section{DISCUSSION}

In this research work, the most lightly infected ecotopes were goat and sheep corrals, followed by perches and finally henhouses. Diotaiuti et al. (2000), in a study that took place in the municipality of Independência, also located in the state of Ceará, obtained similar results, except for the recorded order of infestation: perches were

TABLE I

Type of peridomiciliary ecotopes found in the studied areas of the rural region of the municipality of Jaguaruana, Ceará, Brazil, regarding the characteristics, infestation, and captured species of triatomines

\begin{tabular}{|c|c|c|c|c|c|c|}
\hline \multirow[b]{2}{*}{ Characteristics of the ecotopes } & \multirow[b]{2}{*}{$\begin{array}{l}\text { Existing } \\
\text { N }\end{array}$} & \multirow[b]{2}{*}{$\begin{array}{c}\text { Infestation } \\
(\%)\end{array}$} & \multicolumn{4}{|c|}{ Captured species and percentage of infested ecotopes } \\
\hline & & & $\begin{array}{c}\text { Triatoma } \\
\text { brasiliensis / } \\
\% \text { of ecotopes }\end{array}$ & $\begin{array}{c}\text { Triatoma } \\
\text { pseudomaculata / } \\
\% \text { of ecotopes }\end{array}$ & $\begin{array}{c}\text { Rhodnius } \\
\text { nasutus / } \\
\% \text { of ecotopes }\end{array}$ & $\begin{array}{c}\text { Panstrongylus } \\
\text { lutzi/ } \\
\% \text { of ecotopes }\end{array}$ \\
\hline \multicolumn{7}{|l|}{ Shelters } \\
\hline Wood wall with roofing tile & 124 & 36.3 & $1.319 / 33$ & $51 / 8$ & $2 / 1.6$ & 0 \\
\hline Wood wall with roofing tile and straw cover & 4 & 50 & $74 / 16.1$ & 0 & $3 / 50$ & 0 \\
\hline Wood wall with straw cover & 51 & 9.8 & $165 / 3.9$ & $33 / 7.8$ & $87 / 5.8$ & 0 \\
\hline Wood wall with straw and wood cover & 9 & 44.4 & $11 / 22.2$ & $2 / 22.2$ & 0 & 0 \\
\hline Wood fence & 26 & 0 & 0 & 0 & 0 & 0 \\
\hline Wood perch & 29 & 34.5 & $23 / 10.3$ & $161 / 27.5$ & $3 / 3.4$ & 0 \\
\hline \multicolumn{7}{|l|}{ Piles } \\
\hline Woods & 36 & 36.1 & $191 / 16.6$ & 82 / 16.6 & $26 / 2.8$ & 0 \\
\hline Bricks & 18 & 38.9 & $250 / 27.8$ & $7 / 5.6$ & 0 & $1 / 5.6$ \\
\hline Roofing tiles & 24 & 50 & $171 / 41.7$ & $4 / 4.2$ & 0 & $4 / 4.2$ \\
\hline Straws & 2 & 0 & 0 & 0 & 0 & 0 \\
\hline Total & 323 & 30.3 & $2.204 / 22$ & $340 / 9.9$ & $121 / 2.8$ & $5 / 0.6$ \\
\hline
\end{tabular}

TABLE II

Number of colonies per species of triatomines distributed per colony size, present in shelters of domestic animals

\begin{tabular}{lccc}
\hline \multirow{2}{*}{$\begin{array}{l}\text { Specimen of } \\
\text { triatomines }\end{array}$} & \multicolumn{3}{c}{ Number of colonies per species } \\
\cline { 2 - 4 } per colony & $\begin{array}{c}\text { Triatoma } \\
\text { brasiliensis }\end{array}$ & $\begin{array}{c}\text { Triastoma } \\
\text { pseudomaculata }\end{array}$ & $\begin{array}{r}\text { Rhodnius } \\
\text { nasutus }\end{array}$ \\
\hline 1 to 10 & 26 & 17 & 1 \\
11 to 20 & 10 & 2 & 3 \\
21 to 30 & 3 & 1 & 0 \\
31 to 40 & 5 & 2 & 0 \\
41 to 50 & 5 & 2 & 1 \\
$>50$ & 6 & 0 & 0 \\
\hline Total & 55 & 24 & 5 \\
\hline
\end{tabular}

TABLE III

Number of colonies per species of triatomines distributed per colony size present in piles

\begin{tabular}{lccc}
\hline \multirow{2}{*}{$\begin{array}{l}\text { Specimen of } \\
\text { triatomines }\end{array}$} & \multicolumn{3}{c}{ Number of colonies per species } \\
\cline { 2 - 4 } per colony & $\begin{array}{c}\text { Triatoma } \\
\text { brasiliensis }\end{array}$ & $\begin{array}{c}\text { Triastoma } \\
\text { pseudomaculata }\end{array}$ & $\begin{array}{r}\text { Rhodnius } \\
\text { nasutus }\end{array}$ \\
\hline 1 to 10 & 13 & 7 & 0 \\
11 to 20 & 5 & 3 & 0 \\
21 to 30 & 1 & 0 & 1 \\
31 to 40 & 2 & 1 & 0 \\
41 to 50 & 0 & 0 & 0 \\
$>50$ & 3 & 0 & 0 \\
\hline Total & 24 & 11 & 1
\end{tabular}


TABLE IV

Spearman correlation $\left(r_{\mathrm{S}}\right)$ between the number of captured triatomines and the amount of domestic animals present in each ecotope

\begin{tabular}{lrcc}
\hline Ecotope & $\mathrm{N}$ & $r_{s}$ & $p$ \\
\hline Henhouse & 15 & 0.3829 & 0.1589 \\
Pigpen & 8 & 0.6849 & 0.0609 \\
Goat/sheep corral & 12 & 0.0573 & 0.8597 \\
\hline
\end{tabular}

the most infested ecotopes, followed by henhouses and then goat/sheep corrals.

In successive captures we observed that $T$. brasiliensis tended to infest and colonize shelters or piles containing roofing tiles or bricks, thus making the species population stability evident in these ecotopes in comparison with other ecotopes. Roofing tiles were usually overlapping, either covering a shelter or forming piles; this arrangement offers excellent refuge. A similar situation occurs with bricks, which when parallelly arranged or in piles create microenvironments where triatomines may harbour themselves. Bricks and roofing tiles are made of wet clay and have a porous texture, which may be a thermal insulator and creates microclimatic environments (temperature and humidity) that are favorable to colony formation (Lorenzo et al. 2000).

In the wild, T. brasiliensis inhabits cracks and spaces among rocks (Alencar 1987). The fact that roofing tiles and bricks are made of clay, notably with some constitution characteristics similar to those found in the natural habitat, may explain the preference of this species for these artificial ecotopes. Reparaz and Bar (1984) performed laboratory studies concerning the preference of $T$. infestans for different types of construction materials and they found that this species demonstrates a preference for dry clay rather than other materials.

In this study, T. pseudomaculata displayed preference for wood ecotopes, specially perches made of carnauba wax palm or black quince tree trunks, which provide hiding places in their core or beneath the bark. T. pseudomaculata is an arboreal species that naturally inhabits tree crannies and hollows or bird nests (Alencar 1987, Carcavallo et al. 1999).

$R$. nasutus is also an arboreal species, exclusively of palm trees, which inhabits on the crowns of the trees and bird nests found there (Alencar 1987, Carcavallo et al. 1999). In our area of study this species has only been captured in carnauba wax palms (Sarquis 2003), hence it has proven to be the only species living in the crowns of palm trees. According to Lent and Wygodzinsky (1979) and Romaña et al. (1999), palm trees are natural ecotopes for the species of genus Rhodnius, and they can be considered as ecological indicators of a risk area for Chagas disease. In the peridomicilium, $R$. nasutus was captured in other ecotopes containing perches and woodpiles, nevertheless their preferred material was palm tree straw used as roofing for henhouses.

In the present assay, we could not find $R$. nasutus cohabitating with any other species of triatomine in the wild. Nevertheless it was not encountered isolated in the peridomiciliary environment. These data lead us to believe that there is an adaptation of the species, probably resulting from the change in habit due to the scarcity of food and reduction of vegetation, which forced it to cohabitate with other species.

T. infestans domiciliation has made control easier, however species with wild or semi-domestic habits, such as $T$. brasiliensis, T. pseudomaculata, and R. Nasutus, are extremely difficult to control. The Chagas Disease Control Program of the state of Ceará has been spending a great effort to maintain a regular control in and around the houses of the Jaguaruana municipality; even so, these triatomines tend to reinvade dwellings soon after chemical insecticides have been applied. The natural habitat for these species, represented by caatinga, has ecological characteristics that facilitate their development, therefore they are almost always found in large densities. On the other hand, deforestation together with other human interference in this environment has caused displacement of these insects to peridomiciles. Large populations of domestic animals can be found in these environments and their shelters can also host insects. The frequent presence of sinantropic animals, in conjunction with the accumulation of materials in the shelters, provides all the conditions for triatomine colonization. Furthermore, these artificial ecotopes usually offer innumerable hiding places, some of them totally inaccessible to spraying, thus facilitating development and recolonization of the remaining specimens. As stated by Rabinovich (1985), insect vector population in domiciliary conditions associated to T. cruzi infection contitutes an essencial risk factor for human infection. Hence, with the reference to a previous paper (Sarquis et al. 2004), the high natural infection index of these hematofages which are frequently found colonizing intradomiciles in Jaguaruana suggests that epidemiological surveillance must be constant in order to insure that these species do not become a severe public health problem.

\section{ACKNOWLEDGEMENTS}

To the Health Department of the State of Ceará and to the City Hall of Jaguaruana, for the logistic support and cooperation. To Mr Mitchell R Lishon, for assistance with the English revision.

\section{REFERENCES}

Alencar JE 1987. Historia Natural da Doença de Chagas no Estado do Ceará, Imprensa da Universidade da UFC, Fortaleza, $341 \mathrm{pp}$.

Bezerra CMM, Garcia HM, Lima JWO 2004. Avaliação do desempenho do programa de Controle da Doença de Chagas (PCDCh), no município de Jaguaruana, Ceará, 1975 a 2002. Rev Soc Bras Med Trop 37 (Supl. I): 30.

Carcavallo RU, Rodriguez MEF, Salvatella R, Curto de Casas SI, Sherlock IS, Galvão C, Rocha DS, Girón IG, Arocha MAO, Martinez A, Da Rosa JA, Canale DM, Farr TH, Barata JMS 1999. Habitats and related fauna. In RU Carcavallo, IG Girón, J Jurberg, H Lent (eds), Atlas dos Vetores da Doença de Chagas nas Américas, Vol. II, Fiocruz, Rio de Janeiro, p. 561-600. 
Costa J, Almeida CE, Dotson EM, Lins A, Vinhaes MC, Silveira AC, Beard CB 2003. The epidemiologic importance of Triatoma brasiliensis as a Chagas disease vector in Brazil: a revision of domiciliary captures during 1993-1999. Mem Inst Oswaldo Cruz 98: 443-449.

Diotaiuti L, Faria Filho OF, Carneiro FCF, Dias JCP, Pires HHR, Schofield CJ 2000. Operational aspects of Triatoma brasiliensis control. Cad Saúde Púb 16 (Supl. II): 61-67.

Lent H, Wygodzinsky P 1979. Revision of the triatominae (Hemiptera, Reduviidae), and their significance as vector of Chagas' disease. Bull Amer Mus Nat Hist 163: 125-520.

Lima MM, Sarquis O, Mac Cord JR, Gomes TF, Coutinho CFS, Sposina R, Oliveira TG, Bóia M 2004. Levantamento da fauna de triatomíneos e da infecção por Trypanosoma cruzi em três localidades da região periurbana de Jaguaruana/ CE, Brasil. Rev Soc Bras Med Trop 37 (Supl. I): 183.

Lorenzo MG, Guarneri AA, Pires HHR, Diotaiuti L, Lazzari CR 2000. Aspectos microclimáticos del habitat de Triatoma brasiliensis. Cad Saúde Púb 16 (Supl. II): 69-74.

Rabinovich JE 1985. Ecologia poblacional de los triatominos. In RU Carcavallo, JE Rabinovich, RJ Tonn (eds), Factores Biologicos y Ecológicos de la Enfermedad de Chagas, OPS, Buenos Aires, p. 121-148

Reparaz VL, Bar ME 1984. Preferência de Triatoma infestans (Klug, 1834) y Triatoma sordida (Stal, 1859) por distintos materiales de construccion. Facena 5: 57-70.
Romaña CA, Pizzarro JCN, Rodas E, Guilbert E 1999. Palm trees as ecological indicator of risk areas for Chagas disease. Trans $R$ Soc Trop Med Hyg 93: 594-595.

Sarquis O 2003. Aspectos Epidemiológicos da Doença de Chagas na Zona Rural de Jaguaruana, Ceará, Brasil, PhD Thesis, Fiocruz, Rio de Janeiro, 116 pp.

Sarquis O, Borges-Pereira J, Mac Cord JR, Gomes TF, Cabello PH, Lima MM 2004. Epidemiology of Chagas disease in Jaguaruana, Ceará, Brasil: I. Presence of triatomines and index of Trypanosoma cruzi infection in four localities of a rural area. Mem Inst Oswaldo Cruz 99: 263-270.

Silveira AC 2002. O controle da doença de Chagas nos países do Cone Sul da América, In AC Silveira, El Control de la Enfermedad de Chagas en los Países del Cone Sur de América. História de una Iniciativa Internacional, 1991/ 2001, Opas, Brasília, p. 15-43.

Silveira AC, Vinhaes MC 1998. Doença de Chagas: aspectos epidemiológicos e de controle. Rev Soc Bras Med Trop 31(Supl. II): 15-60.

Silveira AC, Vinhaes MC, Lira E, Araújo E 2001. O Controle de Triatoma brasiliensis $e$ Triatoma pseudomaculata. I Estudo do Tempo de Reposição das Condições de Transmissão da Doença de Chagas por Triatoma brasiliensis $e$ Triatoma pseudomaculata, em Áreas Submetidas a Tratamento Químico Domiciliar, e de Variáveis Ambientais Relacionadas, Opas, Brasília, 86 pp. 